NEMANJA ZVIJER

Faculty of Philosophy University of Belgrade

\title{
Film (de)construction of national identity. The case of Serbian films from the 1990s
}

\begin{abstract}
Zvijer Nemanja, Film (de)construction of national identity. The case of Serbian films from the 1990s. „Images” vol. XXIII, no. 32. Poznań 2018. Adam Mickiewicz University Press. Pp. 15-23. ISSN 1731-450X. DOI 10.14746/i.2018.32.02.

The article deals with the relation between films and the concept of the national identity. These issues are discussed on the example of Serbian cinema in the 1990s. Using Anthony Smith's approach to the visual representation of national identity, the ways in which films in Serbia construct national identity is discussed. After that, several films are analyzed that critically question the concept of nationalism. This analysis demonstrates how ideology, in this particular case, nationalistic ideology, at the semantic level can be related to films, one of the most influential segments of popular culture.
\end{abstract}

KEYWORDS: films, nationalism, national identity, Serbia.

The 1990 os were a particularly turbulent period in Europe, as the collapse of the USSR and the fall of Berlin caused the end of European socialist regimes. In the Balkans, especially in socialist Yugoslavia, the aforementioned period was even more traumatic because of the armed conflicts which marked the ultimate end of that country. The new states formed after the collapse of Yugoslavia turned to strengthening their own national identities within a nationalist ideology. Almost overnight national identities replaced previous identity orientations (most often those of a leftist or revolutionary kind) in a very wide-scale process, one which was characteristic not only of the post-Yugoslav space.

Bearing in mind the strong wave of nationalism that hit the post-Yugoslav space, the question might be posed as to how nationalist ideology influenced other areas of society, such as popular culture. Since popular culture is a very broad area, attention may be directed to film as one of the most influential segments of it. Accordingly, based on the example of films produced in Serbia during the 1990 s, whether and to what extent the dominance of nationalism left a certain mark on film production will be considered in this paper. These issues will be examined through the ways in which such films visually represented national identity, one of the basic elements of nationalist ideology itself.

Some authors believe that "films are powerful cultural agents that interact with multiple discourses and shape concepts of nation-
Images vol. XXIII/no. 32

Poznań 2018

ISSN 1731-450X
Introductionary notes

National identity in a visual perspective 
ality by telling stories and showing pictures about the nation".[1] One of the ways to operationalize nationalist discourse in film is through an analysis of the modes of film constructions of national identity. In terms of the visual arts, Anthony Smith states that national identity can be visually constructed on two levels - one refering to national heroism, the other related to shaping the so-called "ethnic atmosphere". According to Smith, national heroism implies "examples of virtue" (exempla virtutis) associated with the psychological tension, moral choices and personal drama of the protagonists. [2] The second level of the visual construction of national identity refers to the shaping of the "ethnic atmosphere", through dimensions such as character development, historical reconstruction, pictorial tableaux, accessories, ethnoscape and the "people". The shaping of the "ethnic atmosphere" includes the evocation and representation of nationhood in all its historical and geographical varieties in as naturalistic a manner as possible. [3] More specifically, the development and progress of a film character may serve as a metaphor for the development and progress of the nation itself, while historical reconstruction "provides a 'historical map' of the national past in order to bind the spectator more firmly to the present national identity".[4] Pictorial tableaux (vivid scenes) influence the audience more easily and unobtrusively, while accessories (costumes and props) contribute to greater authenticity. Besides this, ethnoscapes clearly mark the national territory inhabited not by ordinary people, but by "the people" with a distinctive ethnic culture.[5]

A self-victimization component may be added to Smith's levels of the construction of national identity, since the representation of the nation itself as a victim forms a significant part of the nationalist narrative. It can be said that "one of the characteristic of Serbian nationalism, which can be recognized in almost all small nations, is selfpity expressed as the discourse of self-victimization".[6] The discourse of self-victimization is important because it emphasizes the incomparability of its own victim status and, at the same time, legitimizes nationalism itself.

Film construction of national identity in Serbia
Both levels used for the visual construction of national identity, national heroism and shaping the "ethnic atmosphere", were very directly expressed in the film The Dagger (Nož, 1999). National heroism is embodied in the film's main character Alija/Ilija (Žarko Laušević), who suffers a personal drama because as a baby he is taken away from his Serbian family and placed into a Muslim one. The film shows Alija's feeling of discomfort (he has nightmares in which he dreams about the
[1] L. Berezhnaya, C. Schmitt, Introduction, in: Iconic Turns: nation and religion in Eastern European cinema since 1989, Leiden-Boston 2013, p. 13.

[2] A. Smith, Images of the nation. Cinema, art and national identity, in: Cinema and Nation, eds. M. Hjort, S. Mackenzie, London 2000, p. 48.
[3] Ibidem, p. 51.

[4] Ibidem, p. 52.

[5] Ibidem, p. 56.

[6] J. Bakić, Jugoslavija: razaranje i njegovi tumači, Beograd 2011, p. 280. 
so-called "blood tax"[7]), and this serves as an example of psychological tension. The personal drama of the main protagonist and the psychological tension reaches its peak when he discovers his true national identity.

The scenes in which the main character suffers from nightmares implicitly suggest that this is a consequence of accepting a national identity that is not "really his". In this way, nationhood is viewed from a primordial perspective, according to which individuals by their birth necessarily belong to certain nations.[8]

National identity is also emphasized through the "ethnic atmosphere", especially through a "historical map" showing how Muslims in post-Yugoslav space originate from Serbs. This is particularly evident in the scenes where "Sikter" Efendi (Aleksandar Berček) explains to Alija how both of them are Serbs by origin. Since these scenes have a strong emotional potential and play an important role in the narrative structure of the film (because the main character discovers his "true nationality"), their function is most likely to point out the national past. Furthermore, in showing the relationship between the Muslim and Serbian national collective, the film emphasises that the former is an off-shoot of the latter, with the implication that the latter, being older, has some form of greater legitimacy.[9]

In addition to the "historical level", national identity is also visually constructed through vivid scenes of violence. This violence is mainly directed towards the Serbian nation, and the main function of these scenes is to build the status of the victim. Like the vivid scenes, the ethnoscapes (in this case rural Herzegovina) are also linked to the self-victimization discourse at the beginning of the film in scenes depicting the murder of a Serbian family and kidnapping of their child.

The film Balkan Rules (Balkanska pravila, 1997) also provides a relatively coherent picture of national identity. This film deals with confrontations in the Yugoslav state security agency. One of the main protagonists, agent "Old Man" (Lazar Ristovski), embodies both of the levels Smith mentions. On the one hand, this character may represent national heroism ("examples of virtue") associated with his moral choices and personal drama (concerning his job in the agency and relationship with his son). Agent "Old Man" is both mentally and physically strong, but also full of kindness and concern, and at the same time, his character has action scenes and humorous lines as well as some almost mythological components. All of these characteristics may be linked to the character development, an important dimension for shaping the "ethnic atmosphere".

[7] "The blood tax" (in Serbian "danak u krvi”) was a type of a taxation in the Ottoman Empire which referred to taking away children from Christian countries and their conversion to Islam for the needs of the Ottoman army.
[8] J. Bakić, Teorijsko-istraživački pristupi etničkoj vezanosti, nacionalizmu i naciji, "Sociologija” 2006, no. 48 (3), p. 233.

[9] A.J. Horton, Vignettes of Violence. Some recent Serbian screen attitudes, in: idem, The Celluloid Tinderbox: Yugoslav Screen Reflections of a Turbulent Decade, London 2000, p. 106. 
In addition, in Balkan Rules two motifs, that of victim and that of betrayal, are related to the construction of national identity. The first motif shows that Serbia was the greatest victim, both in the First World War (this can be seen in the main hero's speech at the beginning of the film), as well as in socialist Yugoslavia (the film alludes to a conspiracy against the Serbs). Similary, the betrayal motif shows how the Serbian agents have betrayed each other, but the Croats' betrayal of the trust of Serbs in Yugoslavia is also emphasized.

A more subtle visual construction of national identity is present in war-related films, such as Pretty Village Pretty Flame (Lepa sela lepo gore, 1996) and Underground (Podzemlje, 1995). At first sight, it may seem that in the film Pretty Village Pretty Flame national identity has been visually deconstructed, because a certain ironic distance towards some nationalistic motifs is often present. This opinion is shared by Daniel Goulding, believing that "the film strongly condemns the cynical appropriation and vulgarization of Serbian national myths by Milosevic's regime".[10] However, it may be noted that the treatment of nationalistic motifs in this film leads to their reproduction, because they were subjected more to postmodern ironic play, rather than rational and explicit criticism. In that sense, the film may be said to have "reflected the national trends that dominated the socio-political and cultural sphere"[11].

In a similar manner, the main characters in the film symbolise the heterogenity of the nation (because they have different social backgrounds and different motivation for going to war), but also the unity of the nation when it is most important, at times of existential threat. So, it could be said that the heterogeneous character of the nation is irrelevant, because as soon as the threat of imminent danger occurs, all the differences between people become unimportant and the nation unites. In the film Pretty Village Pretty Flame there is no visual construction of national identity through Smith's dimensions of national heroism or the shaping of the "ethnic atmosphere", but a more subtle visual stylization of a national identity "decorated" with dark sides.

Accordingly, this "decoration" is more stylistic than critical in nature, and could be related to Michael Herzfeld's concept of cultural intimacy. Cultural intimacy could be defined as

\footnotetext{
the recognition of those aspects of a cultural identity that are considered a source of external embarrassment but that nevertheless provide insiders with their assurance of common sociality, the familiarity with the bases of power that may at one moment assure the disenfranchised a degree of creative irreverence and at the next moment reinforce the effectiveness of intimidation.[12]
}

[10] D. Goulding, Raspad Jugoslavije: Kinematografski odrazi, "Hrvatski filmski ljetopis" 1999, no. 19-20, p. 193.
[11] P. Levi, Raspad Jugoslavije na filmu, Beograd 2009, p. 210.

[12] M. Herzfeld, Cultural Intimacy: social poetics in the nation-state, New York and London 2005, p. 3. 
The concept of cultural intimacy, therefore, implies that national identity may contain some elements which deviate from the idealized image of the nation, but at the same time do not essentially undermine that idealized image. Because of that, Herzfeld states that cultural intimacy "can take the form of ostentatious displays of those alleged national traits [...] that offer citizens a sense of defiant pride in the face of a more formal or official morality and, sometimes, of official disapproval as well. These are the self-stereotypes that insiders express ostensibly at their own collective expense".[13].

This could be the case with the dark, ironic and satirical image of the national identity represented in the film Pretty Village Pretty Flame. From the perspective of an official, highly formal nationalist ideology, this image can create an "embarrassment, rueful self-recognition [...] the key markers of what cultural intimacy is all about".[14] Although it may sound paradoxical, Herzfeld believes that the concept of cultural intimacy is "an antidote to the formalism of cultural nationalism", but at the same time, "nationalism and cultural intimacy are entwined in a mutual dependence".[15] Cultural intimacy, in a certain sense, may serve to legitimize any possible diversion from a strict nationalist track, especially in those cases in which the criticism of the nationalist ideology is not substantial, but rather playfully postmodern.

In Underground, cultural intimacy has been coded in a very similar way, because in this film the "alleged national traits" also have a hyperbolic and humorous dimension, often providing the "sense of defiant pride" which Herzfeld spoke about. The two main characters in this film are portrayed as people with extremely Dionysian characteristics, who have a high propensity for alcohol, women and physical conflicts. Although this overemphasis may be seen as a certain critique of the national stereotype, it is more likely an indirect glorification of the same stereotype, so the national identity is visually constructed as very alive and vibrant.

National identity constructed in this way can be linked to the concept of "the wild man of the Balkans" coined by Fredric Jameson. According to Jameson, the main ideological function of this concept is to maintain the stereotype that the southern Slavs are naturally violent and aggressive and that they need order, whether imposed from the outside or from within.[16] The concept of "the wild man of the Balkans" represents the Western view of the Balkans and its inhabitants, and therefore has relatively negative connotations, but in the film Underground those negative stereotypes are given positive allusions. This film reverses the meaning of these stereotypes and through that process constructs a romanticized representation of the nation with a certain dose of exoticism.[17]

[13] Ibidem.

[14] Ibidem.

[15] Ibidem, pp. 8-14.
[16] F. Jameson, Thoughts on Balkan cCinema, in: Subtitles: on the Foreignness of Film, eds. A. Egoyan and I. Balfour, London 2004, p. 234. [17] Sociologist Dušan Bjelić believes that "Taking the cliché of the "wild Balkan Man" produced by the 
Film deconstruction of national identity in Serbia global media through their coverage of the ethnic war and the United Nations sanctions imposed upon Serbia and Montenegro, Serbian cinemasucceeded in exploiting the stereotype brilliantly, using Hollywood's own language of cinema to turn the global media against itself" (D. Bjelić, Global aesthetics and the Serbian cinema of the 1990s, in: East European Cinemas, ed. A. Imre, New York 2005, p. 103).

[18] It could be said that, "Except the 'internal' robbery, the war was a polygon for the cruelest kind of robbery in areas affected by war. The paramilitary formations, with the silence of police and military authorities, were looting civilian population regardless of their ethnicity. A new category of war criminals and robbers was born - a weekend warriors. Some people were going to the battlefield on the weekends, just because of robbing, as if it were additional work" (D. Jovanović, Prilagođavanje. Srbija i moderna: od strepnje do sumnje, Beograd 2012, p. 395).

[19] Ethnologist Ivan Colović points out that this practice had started in the second half of the 1980's in the print media (I. Čolović Bordel ratnika, Beograd 2007, pp. 5-21), but in the 1990's the media glorification of members of criminal groups particularly intensified. 
the general state of society, and points out that this state, among other things, was a consequence of widespread nationalism.

Similarly, the critique of nationalism and nationalistic exclusiveness is also present in the film Premediated Murder (Ubistvo $s$ predumišljajem, 1995). In this film, nationalist discourse is framed by two characters, the young soldier Bogdan (Nebojša Glogovac) and his older war companion Muždeka (Radoslav Milenković). The first one symbolises romantic nationalism, strongly immersed in national myths and epics, and the second, chauvinistic nationalism characterized by complete national exclusivity and intolerance.[20]

The critical visual construction of nationalism in this film may be interpreted in two ways. On the one hand, the film suggests that nationalism is "imported", because it comes from the other side of the River Drina (it was emphasized that both characters were not from Serbia). Therefore, nationalism was not something characteristic of the "domestic field", and at the same time, the "domestic collective" is cleansed from nationalist radicalism. In this way, nationalism is represented as something that comes from the outside.

On the other hand, the film suggests that nationalist aggression was typical of rural areas (the fact that both characters were from such areas was also emphasized). The critique of nationalism in this film refers to the type of critique which, according to Stef Jansen, indicates that "rural primitivism" was the main cause of the nationalist conflicts after the collapse of Yugoslavia.[21] In principle, such a critique stems from the assumption that rural areas, villages and provinces were a kind of reservoir of radical nationalism, while the city was a place of opposition and critical thinking.[22]

Premediated Murder uses this critical dicourse. One of the leading characters in the film is Belgrade journalist Jelena (Branka Katić), who is represented as urban, sharp, immediate, emancipated and completely antinational. She is the antithesis of the two aforementioned characters, and her attitude is often expressed through the criticism and ridicule of the nationalist myths and beliefs of the soldier Bogdan. The ideological confrontation of these two characters, who are also involved in an emotional relationship, points to the distinction between rural and urban mindsets. In this way, nationalism and war aspirations, as well as the responsibility for the war itself, are linked to rural areas.

Although the critique in this film is, in a certain sense, one-sided, the critique still exists. A slightly different kind of criticism is present in the film The Powder Keg (Bure baruta, 1998). This film does not directly refer to nationalism so it could be noted that "Nationalism is, in

[20] On the theoretical level these variations within the film construction of a nationalist discourse could be marked as conservative and expansionist nationalism (A. Heywood, Političke ideologije, Beograd 2005, pp. 181-186).
[21] S. Jansen, Antinacionalizam, Beograd 2005, p. 110.

[22] Ibidem, p. 143. 
fact, pointedly absent from the story, appearing only as a fictive cloud hovering over the city as if in someone else's imagination, or as news streaming from a cab's radio or from a television".[23]

Smith's dimension of ethnoscapes in this film has a deconstructive character, because it does not proudly mark the recognizable national territory. The ethnoscapes are embodied in abandoned and ruined city squares inhabited by people who are impoverished, desperate and aggressive to the extreme. Hence, "the nation is reduced to an assemblage of violent man, who have internalized their identity as a menace brought about by historical and political forces beyond their reach or understanding".[24] In the very gloomy atmosphere of the film, most of the scenes abound with images of violence, and almost every character either commits violence or is a victim of it.

Violence in The Powder Keg is not aestheticized in the Hollywood manner, but is more raw and reduced, and therefore represents an instrument of relatively open criticism. According to Dina Ioradnova, "the violent protagonists of Goran Paskaljević's Powder Keg destroy friends and acquaintances, and, along the way, destroy themselves as well. Here, the ultimate repercussions of violence are suffered equally by perpetrator and victim; violence is as much self-destructive as it is destructive".[25] In this film, violence comes strictly from the inside, and does not cross the boundaries of its own national collective. Violence and aggression are therefore a feature of national identity, and this is the way this identity is indirectly deconstructed through the film.[26]

Concluding remarks

It may be concluded that widespread nationalist ideology left its mark on a certain number of films produced in Serbia during the 1990s. In some cases, this influence was manifested in the visual construction of national identity. This means that in some films national identity was constructed through the levels and dimensions of Anthony Smith's approach. However, in some other films nationalist identity, in a certain sense, was deconstructed through critical reconsideration of certain segments of nationalist ideology.

In a broader sense, this analysis shows how the dominant ideology in a given society may impact on popular culture. This influence may have both a "positive" and "negative" character. In the first case, ideological meanings may be reproduced within popular culture through different segments such as films, popular music, comics etc. On the other side, the influence of dominant ideology on popular culture could follow a reverse direction, and in that case, popular

[23] D. Bjelić, op.cit., p. 108.

[24] T.Z. Longinović, Playing the Western eye: Balkan masculinity and post-Yugoslav war cinema, in: East European Cinemas, ed. A. Imre, New York 2005, p. 43. [25] D. Iordanova, Cinema of Flames, London 2001, p. 164 .
[26] Dušan Bjelić states that both films, The Wounds and The Powder Keg "focus on urban violence, mostly by urban Serb against urban Serb [...], these Belgrade films have produced an urban image that in itself subverts the pastoral semiotics of Serbian nationalism..." (D. Bjelić, op.cit., p. 107). 
culture may serve as a symbolic resistance to dominant ideological patterns, in the way in which John Fiske[27] or Douglas Kellner[28] wrote about it.

Bakić J., Jugoslavija: razaranje i njegovi tumači, Beograd 2011.

Bakić J., Teorijsko-istraživački pristupi etničkoj vezanosti, nacionalizmu i naciji, “Sociologija” 2006, no. 48 (3), pp. 231-264

Berezhnaya L., Schmitt Ch., Introduction, in: L. Berezhnaya, Ch. Schmitt, Iconic Turns: nation and religion in Eastern European cinema since 1989, Leiden-Boston 2013

Bjelić D., Global aesthetics and the Serbian cinema of the 1990s, in: East European Cinemas, ed. A. Imre, New York 2005

Čolović I., Bordel ratnika, Beograd 2007

Fiske J., Popularna kultura, Beograd 2001

Goulding D., Raspad Jugoslavije: Kinematografski odrazi, "Hrvatski filmski ljetopis" 1999, no. 19-20, pp. 189-208

Herzfeld M., Cultural Intimacy: social poetics in the nation-state, New York-London 2005

Heywood A., Političke ideologije, Beograd 2005

Horton A.J., Vignettes of Violence. Some recent Serbian screen attitudes, in: A.J. Horton, The Celluloid Tinderbox: Yugoslav Screen Reflections of a Turbulent Decade, London 2000.

Iordanova D., Cinema of Flames, London 2001

Jameson F., Thoughts on Balkan cinema, in: Subtitles: on the foreignness of film, eds. A. Egoyan, I. Balfour, London 2004

Jansen S., Antinacionalizam, Beograd 2005

Jovanović Đ., Prilagođavanje. Srbija i moderna: od strepnje do sumnje, Beograd 2012

Kellner D., Cinema Wars, Oxford 2010

Levi P., Raspad Jugoslavije na filmu, Beograd 2009

Longinović T.Z., Playing the Western eye: Balkan masculinity and post-Yugoslav war cinema, in: East European Cinemas, ed. A. Imre, New York 2005

Smith A., Images of the nation. Cinema, art and national identity, in: Cinema and Nation, eds. M. Hjort, S. Mackenzie, London 2000

[27] J. Fiske, Popularna kultura, Beograd 2001

[28] D. Kellner, Cinema Wars, Oxford 2010 